\title{
Species diversity of the Anatidae family as an indicator of sustainable development of territories (on the example of reservoirs of the Ulagan Plateau (Eastern Altai)
}

\author{
A.N. Konunova, O.V. Safonova*, O.P. Vozniychuk \\ Gorno-Altai State University, Department of Biology and Chemistry, 649000, Gorno-Altaisk, Russia
}

\begin{abstract}
The article presents the results of ornithological studies carried out on the Ulagan plateau (Eastern Altai) due to increasing anthropogenic influence. This paper presents a species overview and features of the nesting biology of some species of the Anatidae Family. Considerable attention is paid to the features of spring arrivals, the course of nesting processes, spring and autumn migrations. The paper analyzes data on egg laying and nesting dates. This process includes such periods as: the beginning of oviposition, the period of mass oviposition and the latest ovipositions, the dates of the meetings of downy jackets, flaps, the dates of flights and the beginning of accumulations in preparation for long-distance migration are described. In the territory of the Altai Republic, this problem has been little studied and requires further research.
\end{abstract}

\section{Introduction}

The last decades have been characterized by a significant increase in anthropogenic impact on the nature of Gorny Altai. There are fewer and fewer biocenoses that are not involved in economic and recreational activities in the territory of the Altai Republic. However, sustainable development of territories is possible only if the environment and resources are preserved. The study area, in recent years, has become very popular among tourists who make a significant contribution to the anthropogenic load in the territory of the original habitats of aquatic and near-water birds. In this regard, the study of the avifauna of mountain reservoirs is quite relevant. Moreover, a significant part of the studied representatives of the avifauna are of interest not only from the point of view of biodiversity, but also have a hunting and commercial value. These are traditional hunting grounds for the local population and tourists.

Avifauna is one of the important components of the animal world in general and the local area in particular. Scientific knowledge of it is a reflection of the process of the historical development of nature [1].

Waterfowl and near-water birds are one of the numerous, diverse groups of avifauna of the Altai Republic. In the eastern physical-geographical province, which includes the

\footnotetext{
*Corresponding author: oksvarias@mail.ru
} 
Ulagan Plateau, waterfowl also belong to the most diverse groups in terms of species, which determines their great importance in the biocenoses of this province. Information on the ecology of birds in the highlands of Gorny Altai is presented in separate papers [2-9]. Nevertheless, within the study of references, there is an insufficient number of studies on the topic under study [15-17] and they do not affect this territory. The study area is located away from the main roads; therefore, much of the avifauna data for this area is fragmentary.

\section{Material and Methods}

The works took place in the territory of the Ulagan administrative region, it is located in the forest-steppe high-mountain zone of the eastern part of the Altai Republic. The region is rich in water resources. Hydrography is represented by large rivers: Chulyshman, Bashkaus and many small, inaccessible rivers.

The Chulyshman River is the main largest tributary of the southern part of Lake Teletskoye. It flows out of the high-mountainous Lake Julukul at an altitude of 2,200 m. Length is $241 \mathrm{~km}$, catchment area of the river basin is 16.8 thousand $\mathrm{km}^{2}$.

The main water artery of the study area is the left tributary of the Chulyshman, r. Bashkaus, $219 \mathrm{~km}$ long. The river starts from the eastern part of the Kurai ridge. Tributaries are such rivers as Kubadra, Bolshoi Ulagan, Kara-Kudyur and others. Also, studies were carried out in different lake areas. N.G. Seledtsov (1963) identified bottom moraine glacial lakes and moraine-dammed lakes (in the upper reaches of the Chibit, Karakudur, and Saryachik rivers) in Eastern Altai [10]. There are about 40 lakes in total. In the vicinity of Ulagan and the upper reaches of the Bolshoi Ulagan and Saratan rivers, there are mainly small lakes in area.

The study area includes the interfluve of Chulyshman and Bashkaus. Materials were collected between 1998 and 2019. From 1998 to 2008, the observations were regular, from 2009 to 2019 - in certain years $(2010,2012,2015,2016,2019)$.

\section{Results and Discussion}

In the study area, waterfowl are represented by the following orders: Anseriformes, Gaviiformes, Podicipitiformes, and some Gruiformes. However, the paper presents data on the nature of stay and nesting of some representatives of only the Anatidae family.

\section{Anser fabalis}

The species is found on migration. 5 individuals recorded on May 21, 2000 in the eastern part of the Kabak-Taiga ridge, and in the same place a flock of 6 birds on May 27, 2001 [4]. On the same ridge in the Tuskol tract - at the end of September. On August 29, 2005, a flock of 5 birds was recorded at Lake Uzunkol.

\section{Anser indicus}

On the Ulagan Plateau, we first encountered it in the valley of the Lower Ildugem River (the left tributary in the upper reaches of the Bashkaus River). Here on August 23, 1998 there was a flock of 16 birds, and on July 10, 1999 a brood of 4 well-fledged chicks. On July 20, 2005, a flock of 5 birds was met near the Kyskashtu-Oyik ridge.

\section{Cygnus cygnus}

In the area of our study, swans are found only on flights. Every year from 1999 to 2016 at the spring migration along the valley of the river Bashkaus flocks of 20 to 35 birds were recorded from April 15 to May 3. On the autumn migration on October 3, 1999, a flock of 13 individuals was noted, on September 18, 2000, a flock of 9 birds on the bank of the 
Kubadra River, on September 24, 2001 - 15 individuals in the Bashkaus river valley, here a flock of 10 individuals was observed on September 20, 2016.

Tadorna ferruginea

The species appears in mid-March. Tadorna ferruginea fly in pairs, sometimes in small flocks, the very first. In March, early April, they can often be seen on snow-free areas in river valleys, along roads, in villages near residential buildings. For 15 years, about 300 individuals of these birds were visually observed in the surveyed territory, among which there were single blank individuals. Over the entire period of observations on the Ulagan Plateau, it can be assumed that more than 50 pairs nest here.

Tadorna ferruginea building nest recorded on April 11, 2001. Laying the eggs begins in late April, early May. On the Saryachyk lakes of the Chibit lake region on April 26, 2000 an incomplete clutch of 4 eggs was found, on the next visit, April 30, 2000, there were 8 eggs in the clutch. Late nesting was also noted for the Saratan reservoirs, where 2 fresh clutches were found on June 7, 2002 and June 1, 2003. Of 12 nests, 6 were located in a depression between the roots of a willow and a poplar, 4 on the ground among bumps, 2 under the cover of a Kuril tea bush. In 2003, in the Turalu tract, on May 29, a nest was found in a rather unusual place for the species, it was at a height of $1.5 \mathrm{~m}$ from the ground in the groove of the stump and was neatly covered with spruce twigs. Clutch consisted of 8 pale yellow eggs. When visiting the nest on June 4, it was empty, there were remnants of shells on the ground nearby, and 6 downy jackets with their parents were on the stream not far from this place. For the entire time, 17 nests were found, 11 clutches were examined, of which 6 were observed immediately before the ducklings were taken to the flight. The average egg length is $66.1 \mathrm{~mm}$, the width is $44.6 \mathrm{~mm}$. A full clutch consists of 8-11 eggs, on average 9, while five clutches contained 8 eggs, two clutches 9 , one 10 and two 11 eggs.

Downy jackets appear in late May, early June. Downy jackets appeared in different nests in 1998 on May 25 and 26; in 2000 on May 29 and 30, in 2001 on May 23, 25 and 30, in 2002 on June 1, 3, 7 and 12, in 2003 on June 4, and in 2004 on June 6. Later meetings are also known. On July 16, 2005, a female with 4-5 day old chicks was met on Lake Toshtukol. At the end of June, at the beginning of July, you can meet flaps. We observed flaps in 2000 on June 23 and 26, in 2002 on June 23 and 27, in 2003 on July 5 and 7, and on July 11 in 2012.

Youngs can flight in the second half of July and early August. B1999 flying youngs were recorded on August 6, 12, 24, in 2000 on July 23, 28, in 2015 on August 7. The minimum number of chicks in a brood is 4 , the maximum is 12 , and the average is 9 . Autumn long-distance migration occurs in mid-September. Latest date of meeting October 2, 2001, October 4, 2011

\section{Anas platyrhynchos}

Spring arrival at the plateau occurs in the third decade of April, early May. In different years, the earliest arrival was recorded by us on March 23, 2003, on April 5, 2000, on April 10, 1998, and the latest on May 8, 2004.

On nesting mallards were found on the lakes between the rivers Balyktuul and Onysh, on the lakes of the vicinity of Ulagan, Saryachyk lakes. Soon after arrival, mating games can be observed. So, we marked mating games on April 18, 2000 on the Saldukol lake, on April 20 and 21 on the Karakol lake. On April 28, 2001, a couple building a nest near the Turalu tract was observed. The male actively helped the female to build the nest (brought material) and was always there [3].

Early oviposition was recorded on May 12, 2003 (Lake Kochkovatoe) and May 15, 2001 (river backwater on the Bakpalyk river). The dimensions of the nests: D - 255 and $270 \mathrm{~mm}$, the height of the sides above the ground $-90-100 \mathrm{~mm}$, D of the tray -170 and $190 \mathrm{~mm}$, the depth of the tray - 90 and $100 \mathrm{~mm}$. Mostly the nesting occurs in late May and 
early June. Nest with 8 eggs was found near Saldukol Lake on June 11, 1999. The nest was in a small depression in the soil, there was a lot of fluff in it with a large ridge of it.

In the nest found on June 25 in 2001 on Lake Kochkovatoe on July 26, 8 downy jackets were found; 1 chick was caught; its weight was $150 \mathrm{~g}$. On June 10, 2006 a nest with 10 eggs was found. During a visit to the nest on 1 July, one chattering egg and 8 newly hatched chicks were found, which weighed $23 ; 24 ; 26 ; 23 ; 24 ; 26 ; 27$ and 26 grams, after 2 days two chicks were gone. The body length of the caught one-day-old chick was $14.3 \mathrm{~cm}$. On June 22, 2005, broods of 5 and 6 chicks in age of one or two days were met along the Karaozek river floodplain.

The youngs can fly occurs in the second half of August. On August 7, 2000, a brood of fully fledged, but not yet flying youngs were met. On Lake Saldukol, broods of still poorly flying youngs were recorded on August 18, 1999 and August 20, 2000. Well-flying chicks were met in different years from August 25 to September 2. In the Turalu tract on August 26, 2003, a very late brood of 7 small downy jackets was found, probably from repeated clutches. Therefore, mallard ducklings hatch at the end of the second half of June, and the youngs can fly in the second half of August. At the end of August in the first ten days of September, migratory flocks begin to form: a flock of 12-14 birds was recorded in the Karaozek valley on August 29, 2001; a flock of 7 birds was met on August 30, 2002 near the lake Taldukol; flock of 23-25 individuals on Lake Saldukol - September 6, 2003, September 2, 2005 two birds were noticed on Lake Toshtukol.

\section{Anas crecca}

In spring, this teal appears in the second half of April. In 2000, on April 17, a single bird was seen in the Karatyt tract. In 1999, the first teals appeared on April 21. In 2000 and 2001, on April 22, a flock of five pairs and two single individuals appeared on the Elgektukol lake, in 2001, on April 24 a small flock was observed in the vicinity of the Chibilya village. Teal numbers increase by mid-May. When we walked around the lakes on May 17, 2003, we counted 6.5 individuals per $10 \mathrm{~km}$ of the coastline (Konunova, 2001). Teal-whistle nests along the banks of small rivers, along the shores of lakes, in wetlands. Nests were found in the Pervomai and Kyldynkol tracts and in the Saratan river valley. The dimensions of the nests: D - $150 \mathrm{~mm}$, the height of the sides above the ground - 100, D of the tray - 140, the depth of the tray $-90 \mathrm{~mm}$. On July 27, 2002, moving rapidly chicks were found in the Pervomai tract, and in the Bashkaus valley, well-flying youngs were observed in different years from July 20. This means that the youngs can flights at the end of the third decade of July or in the first decade of August. In later broods, the flights occur at the end of the third decade of August (27.08.2001, 29.08.2003). Young female found by E.A. Irisov in the upper reaches of the river Bashkaus on August 7, 1963. She was fully feathered, but the flight feathers had tubules with tassels [9]. The migration flight begins in mid-September. In 2000, on September 12, a flock of 10-12 individuals was recorded in the Bashkaus valley; in 2001 on September 16 near Lake Polovnikovo a flock of about 30 individuals was noticed. Probably, the migration flight continues until mid-October: on the river. Chibitka on October 15, 2011, 2 birds were noticed.

\section{Gray duck (Mareca strepera)}

In the territory of the reserve in the 60 s of the twentieth century, it was observed on Lake Julukul. V.A. Stakheev, a single bird was found in the Kamginsky Bay of Lake Teletskoye on September 6, 1978 [8]. A shot bird from Lake Sugushkol along the Bashkaus River was brought to us on September 2, 2002. In 2005, on September 12, a shot female gray duck was examined near the Saratan River.

\section{Pintail (Anas acuta)}

The spring migration to the Ulagan plateau was registered in mid-April from April 17 to 28. An individual was found at the nesting site, on the lakes of the environs of Ulagan, the Saratanskie lakes and the lakes of the Chibit lake region. Probably, laying the eggs begins 
in the second decade of May. In 2001, on May 25, a nest with 7 eggs was found on Lake Chayokol (Kyldinkol system), $18 \mathrm{~km}$ from the village of Ulagan. A later clutch with 8 eggs was observed on June 25, 2002 in the Oroy tract. Downy jackets-chicks appeared on July 15 , all eight survived to fly up. On June 17, 2016, a nest with an incomplete re-clutch of 5 eggs was found in the Saryachyk tract, from June 18 to 20, the clutch was replenished by 3 eggs, the first clutch with 9 eggs was destroyed by dogs on June 1 . Thus, 5 nests were found, their average dimensions: D of the nest $-220 \mathrm{~mm}$, the height of the sides - 112, D of the tray -163 , the depth of the tray $-85 \mathrm{~mm}$. 5 clutches were examined, in three clutches there were 10; 7 and 9 eggs, in two of them - 8 eggs. Average clutch size is 8.4. The average egg size is $51 \times 38 \mathrm{~mm}(\mathrm{n}=42)$. Youngs in most broods can fly in mid-July.

\section{Anas querquedula}

The spring migration at the Ulagan plateau falls mainly in the third decade of April, migrates in small flocks or pairs: April 20, 2000. -3 birds (Sorlukel lake), April 21, 2001 5 birds. In the interfluve of Balyktuul and Onysh, a nest with 8 heavily hatched eggs was found on June 19, 2000; here on the lakes there are flocks of 3-4 individuals, apparently not nesting. On the lakes in the upper reaches of the Maly Ulagan River, we found a clutch of 10 eggs on June 16, 2011, only 5 chicks hatched safely in this nest, 5 eggs turned out to be "suffocated", a clutch of 9 eggs was found along the middle course of the Saratan River on June 9, 2001. The dimensions of this nest: D - $170 \mathrm{~mm}$, the height of the sides above the ground -100 , D of the tray -160 , the depth of the tray $-110 \mathrm{~mm}$. On June 2, 2012, a nest with 8 eggs was found along the Tuskol River. The dimensions of this nest: D - $190 \mathrm{~mm}$, the height of the sides above the ground -100 , D of the tray - 180, the depth of the tray $80 \mathrm{~mm}$. Two nests were located in the river floodplains in the immediate vicinity of the water, and one nest was located among the thickets of a dwarf birch in a damp place, at a distance of about $250 \mathrm{~m}$ from the water, which is not quite typical for the species. On autumn and spring flights, the Anas querquedula stops at the lakes Sorlukel, Todinkel, Taldukel. In 2003, 23 teals were recorded at Lake Todinkel on 27 September; May 7, 2004 flock of 20-25 individuals in the Bashkaus valley, on September 10, 2015 flocks of 17-30 individuals were observed on lakes Taldukol and Sorlukol.

Red-headed Duck (Aythya ferina)

The spring migration at the plateau is in the first ten days of May. So, the first birds were recorded on May 2, 1998, on April 29, 1999. A flock of 12 individuals was recorded on the Saldukol lake on May 1, 2000. After migration, the first days dives stay in small flocks. They nest mainly on lakes. Nesting was established for lakes in the upper reaches of the Maly and Bolshoy Ulagan rivers, on lakes between the Balyktuul and Onysh rivers and on lakes in the vicinity of Saratan [3]. The nests found were mainly in dry places, in shallow pits. The nests were lined with soft, dry grass. In the nest found on June 12, 1999, there was an incomplete clutch of 5 eggs; in the next 2 days, the clutch was replenished by 2 eggs. Nest dimensions: D - $300 \mathrm{~mm}$, height -180 , D tray -180 , tray depth $-70 \mathrm{~mm}$. On June 6, 2000, a nest with 8 eggs was found on Lake Baliktukol, which was under the cover of a juniper. Nest dimensions: D - $260 \mathrm{~mm}$, height - 150, D tray - 110, tray depth $-60 \mathrm{~mm}$. The timing of the chicks hatching is very extended. When examining the nest on June 27 , 2000, 8 well-diving 4-5 day old ducklings were found. On the lake in the vicinity of Saratan on July 22, 2000, we met a female with six 2-3 day old downy jackets. In most broods, youngs fly well in mid-August. In late broods, the flaps were found on August 23, 2000, on August 25 and 28, 2001. On August 25, 2001, a dead bird was found, probably caught in the net, its weight was 900 grams. In September, early October, dives begin to stray into small flocks. The migration probably continues until the end of October. Single birds were sighted on October 20-23, 2001, October 19-20, 2002, October 16, 2015.

Crested Duck (Aythya fuligula) 
In the study area for 2000-2004, 24 cases of nesting were registered. The fate of 15 broods was traced. There were 9 nests under direct observation. At nesting sites, these ducks appear at the end of the third decade of April. The number increases in May. They are mostly found in pairs. Nesting begins at the beginning of the second decade of May. Oviposition continues throughout June. Two cases of oviposition were recorded at the beginning of July: 2.07.2002 and 6.07.2004. The facts point to a prolonged nesting period. Nests are located on islands and on the embankment, 10-15 meters from the water. Of the 15 nests, 8 nests were located near the previous nesting sites, 1 nest was occupied for two years in a row (2000-2001). Of the 9 observed nests, 8 were on the ground, 1 nest - in an artificial shelter (wooden box). Average dimensions of 9 nests: diameter - $215 \mathrm{~mm}$, side height -85 , tray diameter -190 , tray depth $-60 \mathrm{~mm}$. There were two cases of oviposition in unfinished nests, more precisely, in a small depression on the ground. The eggs were not further incubated. Such "clutches" arise spontaneously during the period of mass reproduction of ducks, when often the physiological readiness of the female to lay an egg does not coincide with the availability of a convenient place for building a nest. Such clutches are often referred to as "abandoned". This explanation is probably also suitable for our cases, since the crested ducks begin to nest later than many ducks and there may not be enough suitable nesting places. The size of the incubated clutches is from 6 to 11 eggs. Hatching of chicks occurs in the third decade of June or the first decade of July. Daily chicks weigh $39 \mathrm{~g}$, their body length is $155 \mathrm{~mm}$. They fly in the second half of August. Autumn long-distance migration ends in mid-October. We recorded 2 wintering ducks on the Maly Ulagan River in the Kuzyu tract on November 28, 2001 and a flock of three birds on the Bashkaus River on December 2, 2003.

\section{Bucephala clangula}

The Bucephala clangula lives along the banks of the taiga rivers mainly in large lakes, which are not very overgrown with grassy vegetation. It appears in the second half of April in spring. They migrate mainly in pairs. On the Maly Ulagan River on the $20 \mathrm{~km}$ route on April 18, 2000, four pairs of birds were counted. On April 19, a flock of 10 individuals (6 females, 4 males) stayed on the lake in the vicinity of Ulagan. In 2001, the first birds in different years were recorded on the Chibitka River on April 21, 23 and 24. On Lake Karaozek on April 26, a flock of 12 birds was recorded on Lake Taldukel [11].

They nests mainly in tree hollows, but isolated cases of nesting in rotten stumps and on the ground have been noted. The eggs are laid in the second half of June. On Lake Balyktukel, Bucephala clangula nested in a rotten larch stump at a height of $2 \mathrm{~m}$; on June 27,2000 , this clutch contained 7 bluish-green eggs, their average size was $55 \times 42 \mathrm{~mm}$. The nest is oval-oblong in shape, its length is $20 \mathrm{~cm}$, the height of the lateral edges is $12 \mathrm{~cm}$, the depth of the tray is $8 \mathrm{~cm}$. Before the examination, they were incubating, the eggs were still warm. If judging by the amount of fluff and absence of a male nearby, hatching was coming to an end. On re-examination, on July 12, a female with 6 approx. 5-6 day old ducklings stayed on the lake. On the Sorulukol lake on June 5, 2001 a nest was found in a hollow of an old dry larch at a height of 6 meters (the depth of the hollow is $18 \mathrm{~cm}$, the size of the taphole is $13 \times 16.5 \mathrm{~cm}$ ). There were 7 eggs in the nest. At the time of examination, there were no parents near the nest; the clutch was probably incomplete. On June 30, here we found a female with 8 downy jackets of 4-5 days of age, which swam and dived well. On July 25, the chicks were well-feathered, swam in groups of 3-4 ducklings. Autumn long-distance migration extends until early November. A flock of 22 individuals (15 females and 7 males) was recorded on Lake Sabatkol on September 21, 2000. On the lakes located along the Aktash - Ulagan road, Bucephala clangula was noted: September 25, October 16, November 2, 2000, September 17, November 4, 2001, September 24, 2002.

White-winged scoter (Melanitta deglandi) 
On the Ulagansky plateau, the first scoters, 4 drakes and 2 females, appeared in the usual spring of 1999, with an average time of its coming at Lake Karakol on May 25. In 2000, on May 31, 20 scoters (12 drakes and 8 females) kept here, on June there were 14 12 birds ( 7 drakes and 5 females). In 1999, a pair of birds (a female and a male) appeared on Lake Todinkel in the upper reaches of the Maly Ulagan on May 29, on June 11 a flock of 7 drakes and 5 females was here, in 2000 on June 12 a flock of 7 males and 5 females was observed. On two lakes of the Chibitsky Lake District, a pair of birds were sighted on June 6, 2000 [12]. On Lake Akkol, which is located on the border of Ulagan and Ongudai districts, from 2000 to 2003, 4 pairs of scoter nested. The first nest found on Lake Akkel on June 9, 2000, contained 3 eggs; upon a visit to this nest on June 13, 6 eggs were found in it. In 2003, 2 nests were found here and 1 brood was observed. On June 14, 2002, a nest with 8 eggs was found in the interfluve of Balyktuul and Onysh. Here, on July 26, there was a flock of 8 scoters ( 2 males and 6 females) and only one female led a brood of six 2-3-dayold downy jackets. In 2002, on June 21, a nest was found on Lake Karakol with a clutch of 9 eggs. Downy jackets on this lake were observed in late July and early August. In 2005, a clutch of 8 eggs was found on Lake Karaozek. In 1999, on June 24, on a lake in the upper reaches of the river Saratan (the right tributary of the Bashkaus) early in the morning, 2 males were observed, and on July 26 on this lake there was a female with a brood of downy jackets and 2 males. During the period from 1999 to 2005, 6 nests were found, 3 nests were in a depression under various shrubs, 1 - under a spruce root, 2 - between willow roots, in the middle of bumps. Average nest sizes: nest diameter $-25 \mathrm{~cm}$, sides height $-16 \mathrm{~cm}$, tray width $-22 \mathrm{~cm}$, depth $-12 \mathrm{~cm}$. The size of clutches is from 6 to 9 eggs (in 1 clutch there were 6 eggs, in $1-7$ eggs, in $3-8$ eggs each and $1-9$ eggs). The average size of the eggs is $62.4 \times 42.3 \mathrm{~mm}$. During the same period, 14 broods were observed.

Autumn migration begins at the end of September and in some years lasts until the end of October. A flock of 12 scoters was found on the Cheybekkol lake in the upper reaches of the Saratan River on September 29, and flocks of 4 to 10 individuals were observed here in the same year until October 8. In 2001, on October 24, a pair of birds was recorded on Lake Karakol. The last birds on the Chibit group of lakes were observed on October 25, 1993 by A.P. Kuchin [4].

\section{Common merganser (Mergus merganser)}

The spring migration of a large merganser to the Ulagan plateau was noted by us in mid-April: in 2000, on the lakes of the vicinity of the village of Ulagan, small flocks of 6 individuals ( 2 males and 4 females) and 8 individuals (4 males and 4 females) were recorded on April 16, and flock of 7 individuals (4 males and 3 females) was recorded on April 20 [3].

Nesting of the common merganser on the Ulagan plateau begins at the beginning of the first ten days of May, but the nesting times for different individuals are very different. In 2003, on May 19, in the valley of the middle reaches of B. Ulagan, a nest was found in a hollow of an old larch, at a height of 4.5 meters. The nest was lined with fresh down, in the clutch there were 8 yellowish eggs. There was no female in the nest, the male kept nearby. The eggs were cold. When visiting on May 21, there were 9 eggs in the clutch, incubation was in progress. Hatching of chicks in this nest took place on June 22, incubation lasted 31 days. The chicks were all day in the nest, on the 23rd in the evening they were not in the nest. After a week, the number of chicks was reduced to 7, they all swam and dived well. Flaps were found in 2000 - August 16-22, 2001 - August 23, 25 and 27. We observed the autumn long-distance migration from the reservoirs of the Ulagan Plateau from the end of September to the first days of November. In the middle of Ulagan village, 2 female mergansers were recorded on November 1, 2004 and November 5, 2010.

In the study area, the order Anseriformes is represented by 17 species, which is $10.1 \%$ of the number of species identified here and $50 \%$ of the species recorded on reservoirs in 
the former boundaries of the Altai Territory together with the Altai Republic [4]. There are 12 species of migratory breeding species. We presented an overview of the species for 14 species, for which a large amount of actual material on the biology of nesting has accumulated. Four species belong to the red book species of the Altai Republic (Anser fabalis, Anser indicus, Cygnus cygnus, Melanitta deglandi). As a result, in the process of ecogenesis, various ecological groups of birds have arisen, which are characteristic of attachment to certain habitats, using certain food and developing, to one degree or another, peculiar adaptations for obtaining them. In previous publications, we showed the division of birds into ecological groups, the division of birds into such groups is conditional, in other regions it may turn out to be unacceptable. Among waterfowl, specialized diving, optional diving (ichthyophages), optional diving, without high food specialization, surface floating and floating in dense thickets of aquatic plants are distinguished. More than half of the duck family are surface swimming species. We classified the common merganser as optional divers, and red-headed duck, crested duck, Bucephala clangula and white-winged scoter as divers without food specialization. In different seasons, occurrence of species is not stable, as well as in long-term periods. Of the previously recorded species, we did not meet such species as: ferruginous duck, Baikal teal, swan goose, black scoter, smew, whitefronted goose. The White Sea population of the common eider has been studied in sufficient detail: in the polynyas of the Dvinsky Bay and in the mouth of the Kandalaksha Bay. In the course of observations in these bays of the White Sea, data on biology were obtained (nesting, spring migrations and long-distance migrations, number) and an analysis of the age and sex structure of the population was carried out [12].

Arrival and migration in spring is in the nature of migrations, and mainly along thawed patches of water bodies. The described species were mainly found in the valleys of the Bashkaus, Bolshoi Ulagan, and Saratan rivers. The first birds appear in pairs (Tadorna ferruginea, mallard), in small flocks (teals), in large flocks (pintail, crested duck, Melanitta deglandi). Representatives of the duck family prefer to nest at a distance of 10 to $100 \mathrm{~m}$ from the water, up to $10 \mathrm{~m}$ from the water the red-headed duck can nest, and further than $100 \mathrm{~m}$ the teals can nest. It is difficult to distribute nests by location, as birds can nest in different ways depending on the circumstances. Just like in other territories of Siberia [13], the very first species that starts building a nest here is a Tadorna ferruginea. The nesting period lasts 5 months from about the beginning of April to the end of August. The timing of the onset of oviposition in most species varied depending on the meteorological conditions of spring, which does not allow us to speak of the constancy of the individual timing of reproduction of each species [14]. Late cold snaps can result in delayed egglaying.

Analyzing the data obtained, it shall be noted that the species diversity of birds directly depends on the habitat conditions, which, in turn, are subjected to anthropogenic impact. The number of species is also influenced by climatic conditions, and this factor over the past decade has left a significant imprint on species diversity.

\section{Conclusions}

1. An increase in the number of tourists creates various types of pollution (noise, light, chemical, etc.), which leads to stressful conditions of biological systems. Therefore, the anthropogenic load on the traditional habitats of birds of the Ulagan Plateau made serious adjustments to the timing of migration, nesting, as well as the number and distribution of representatives of the Duck family (Anatidae) inhabiting this territory.

2. Obvious climate change influenced the timing of the onset of seasons in the study area, which led to transformation of some population indicators of various species of Duck. 
3. In the territory of the Ulagan Plateau, there are 17 species of birds belonging to the Duck family, which is $21.5 \%$ of the total number of registered species.

4. Species of the Duck family can be divided into diving ducks (red-headed ducks, crested ducks, Bucephala clangula, common merganser) and river ducks (Tadorna ferruginea, mallard, teal, pintail, and etc.).

5. By the nature of their stay, most of them are migratory nesting species. Beginning of the spring migration occurs at the end of March, mainly in pairs, and if in flocks, then males predominate. The very first Tadorna ferruginea flies, the very last - a white-winged scoter.

6. The valleys of the Bashkaus and Saratan rivers, as well as the adjacent lakes with overgrown and swampy shores, are favorable for seasonal migrations and nesting of anseriformes. The lakes in the upper reaches of the Bolshoi Ulagan are of little use for nesting.

7. The type of nesting structures depends on the availability of shelters and on the height of the thickets. Duck species nest on the ground, only a few in the hollows of trees (Bucephala clangula, merganser).

8. Oviposition begins at the end of April in $6 \%$ of birds, at the end of May for $25 \%$ of birds and in the second decade of June of $69 \%$ of birds. Under bad weather conditions, the duration of the nesting period decreased, and under warm conditions, it extended. The clutch size in favorable and unfavorable springs did not differ statistically.

\section{References}

1. S. S. Kalinin, K istorii izucheniya klassa Pticy (Aves) v Kurganskoj oblasti, Zaural'skij nauchnyj vestnik, 1(7), 99-105 (2015)

2. A. N. Konunova, N. P. Malkov, Vodoplavayushchie i okolovodnye pticy Ulaganskogo plato $v$ Vostochno-Altajskoj fiziko-geograficheskoj provincii, Bioresursy transgranichnoj biosfernoj territorii (TBT): Rossijskij Altaj, 99-114 (2008)

3. A. N. Konunova, A. P. Kuchin, Rasprostranenie i gnezdovanie rechnyh utok na Ulaganskom plato, Prirodnye usloviya, istoriya i kul'tura Zapadnoj Mongolii i sopredel'nyh regionov, 48-49 (2001)

4. A. P. Kuchin, Pticy Altaya (nevorob'inye) (2004)

5. E. A. Irisov, Sovremennoe rasprostranenie $i$ chislennost' nekotoryh vidov guseobraznyh na Yugo-Vostochnom Altae, Resursy vodoplavayushchej dichi v SSSR, ih vosproizvodstvo i ispol'zovanie, 57-58 (1968)

6. N. P. Malkov, Avtoreferat kandidatskoj dissertacii. Ekologo-geograficheskij analiz avifauny Central'nogo Altaya (1981)

7. Yu. S. Ravkin, Pticy Severo-Vostochnogo Altaya (1973)

8. V. A. Staheev, Pticy Altajskogo zapovednika (2000)

9. P. P. Sushkin, Pticy Sovetskogo Altaya i prilezhashchih chastej Severo-Zapadnoj Mongolii (1948)

10. N. G. Seledcov, N. E. Shpilekova, Saryachikskie ozera Ajgulakskogo hrebta, Nekotorye problemy geografii Gornogo Altaya, 8-10 (1975)

11. A. N. Konunova, Sroki vesennego prileta $i$ proleta vodoplavayushchih ptic Ulaganskogo plato, Sovremennye problemy ornitologii Sibiri i Central'noj Azii. Materialy III mezhdunarodnoj ornitologicheskoj konferencii, 2, 18-22 (2006)

12. Yu. V. Krasnov, M. V. Gavrilo, A. A. Shavykin, P. S. Vashchenko, Polovozrastnaya struktura endemichnoj belomorskoj populyacii obyknovennoj gagi Somoteria mollessima, Doklady akademii nauk, 4, 568-570 (2010) 
13. E. N. Badmaeva, I. YU. Deulin, M. A. Gulyaeva, L. D. Bazarov, C. Z. Dorzhiev, D. M. Dzhamaltudinov, Fenologiya gnezdovaniya guseobraznyh v Bajkalskoj Sibiri, Yug Rossii: ekologiya i razvitie, 1 (2020)

14. A. M. Bolotnikov, S. S. Kalinin, Metodika izucheniya nasizhivaniya iinkubacii u ptic (1972)

15. R. M. Kaminski, H. H. Prince, The Journal of Wildlife Management, 1, 37-50 (1984). Access mode: https://doi.org/10.2307/3808451

16. D. T. Chhetry, Diversity of Wetland Birds around the Koshi Barrage Area, Our Nature, 4 (1), 91-95 (2007). Access mode: https://doi.org/10.3126/on.v4i1.507

17. S. Holopainen, V.-M. Väänäner, A. D. Fox, Landscape and habitat affect frequency of artificial duck nest predation by native species, but not by an alien predator, Basic and Applied Ecology, 48, 52-60 (2020) 